\title{
Sequence variation and haplotypes of lipoxygenase gene LOX-1 in the Australian barley varieties
}

Hongxia Ye $\mathrm{Y}^{1,2}$, Stefan Harasymow ${ }^{2}$, Xiao-Qi Zhang ${ }^{3}$, Blakely Paynter ${ }^{2}$, Dianxing Wu ${ }^{1}$, Michael Jones ${ }^{3}$, Xiaoli Shu ${ }^{1 *}$ and Chengdao $\mathrm{Li}^{2,33^{*}}$

\begin{abstract}
Background: Lipoxygenases are a family of enzymes which catalyse the hydroperoxidation of polyunsaturated fatty acids with a cis, cis-1,4-pentadiene to form conjugated hydroperoxydienes. Lipoxygenase-1 (LOX-1) in barley worsens the flavour and foam stability of beer. It has become a major selection criteria for malting quality in the last few years.

Results: Lipoxygenase activity was investigated in 41 Australian barley cultivars and advanced breeding lines released since the 1950s; the cultivars differed markedly, ranging from 22.3 to $46.5 \mathrm{U} / \mathrm{g}$. The structural gene and its promoter of lipoxygenase- 1 were sequenced from the barley varieties representing different levels of LOX. Based on the analysis of nucleotide and deduced amino acid sequences, two major haplotypes were identified. Barley varieties with lower LOX were classified into three categories based on their pedigrees and sequence variations in the structural gene: (1) barley varieties derived from Canadian varieties with the pre-harvest sprouting susceptible allele, (2) Skiff and Hindmarsh with unique haplotype in the structural gene, and (3) Gairdner and Onslow with an unknown mechanism.

Conclusion: Lipoxygenase activity has been reduced in the malting barley cultivars in the last 60 years although it is only recognized as a malting quality trait recently. There are clear haplotypes of the lipoxygenase structual gene. The polymorphisms detected in the structural gene can be used to design molecular markers for selection of low LOX haplotype. Other mechanisms also existed for controlling lipoxygenase activity. The results suggest that it is possible to develop barley varieties with lower LOX by combination of low LOX-1 haplotype and other trans-regulation factors.
\end{abstract}

Keyword: Lipoxygenase-1, Structural gene, Haplotype, Malting quality, Hordeum vulgare

\section{Background}

Lipoxygenases (EC1.13.11.12) are a family of enzymes which catalyse the hydroperoxidation of polyunsaturated fatty acids with a cis, cis-1,4-pentadiene structure (e.g. linoleic, linolenic and arachidonic acids) to form conjugated hydroperoxydienes. Multiple lipoxygenase isoforms exist in plants, which are characterised by different temporal and spatial distributions during plant development [1]. Three isoforms have been described in barley, two of which-

\footnotetext{
*Correspondence: shuxl@zju.edu.cn; chengdao.li@agric.wa.gov.au ${ }^{1}$ State Key Lab of Rice Biology and Key Lab of the Ministry of Agriculture for Nuclear-Agricultural Sciences, Zhejiang University, Hangzhou 310029, P.R. China Department of Agriculture and Food, Government of Western Australia, 3 Baron-Hay Court, South Perth, WA 6151, Australia

Full list of author information is available at the end of the article
}

LOX-1 and LOX-2-have been purified and characterised from the embryo of germinated seeds. These two isoenzymes clearly differ: LOX-1 presents in both quiescent and germinating barley grains, while LOX-2 appears during germination [2]. LOX-1 produces mainly 9-hydroperoxide from linoleic acid whereas LOX-2 forms primarily 13hydroperoxide from the same fatty acid. LOX-1 has a relatively low pI compared with LOX-2. The two lipoxygenase cDNA sequences from barley have been characterised and chromosomal locations of the corresponding genes have been determined. LOX-1 is encoded by LoxA mapped on chromosome $4 \mathrm{H}$, while LOX-2 is encoded by LoxC on chromosome $5 \mathrm{H}$ [3]. Expression of a third LOX isoform encoded by LoxB, and similar to that of LOX-2, has been

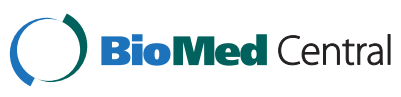

(c) 2014 Ye et al.; licensee BioMed Central Ltd. This is an Open Access article distributed under the terms of the Creative Commons Attribution License (http://creativecommons.org/licenses/by/2.0), which permits unrestricted use, distribution, and reproduction in any medium, provided the original work is properly credited. The Creative Commons Public Domain Dedication waiver (http://creativecommons.org/publicdomain/zero/1.0/) applies to the data made available in this article, unless otherwise stated. 
detected only after germination and the causal gene has not been identified [4].

LOX-1 provides the predominant LOX activity in the mature seed and malt. It can oxidise malt-derived linoleic acid during mashing to 9-hydroperoxyocatadecadienoic acid (9-HPOD) in the production of malt alcoholic beverages, which is an upstream metabolite of the biochemical pathway leading to formation of trans-2-nonenal (T2N) and trihydroxyoctadecenoic acids (THOD). T2N is the source of a cardboard-like odour (a peculiar foul odour given off by degraded beer drinks) and THODs can cause astringency and decrease foam stability of beer resulting in lower quality malt alcoholic beverages. Consequently, it appears that inhibiting LOX-1 activity can inhibit 9HPOD production, making it possible to prevent T2N and THOD generation and effectively maintain beer drink quality. Nowadays, methods for reducing LOX activity (especially LOX-1) both during breeding and malting or mashing have been extensively investigated. In fact, brewing scientists and brewers have successfully developed process-controlling methods to improve flavour stability of beer by preventing enzymatic lipid oxidation. However, beer staling might be better controlled by selecting malting barley cultivars with low levels of LOX, engineering coding gene(s) in barley to control expression of the enzymes, or breeding new cultivars with null-LOX activity. Beers made with the lipoxygenase-1-less (LOX-less) malting barley variety had reduced levels of beer-deteriorating substances, such as T2N and THOD compared to beers made with the control malt. The sensory evaluation results indicate that LOX-less barley variety CDC PolarStar improved flavour stability without affecting other beer characteristics [5]. Carlsberg's research working with Heineken has shown that brewing beer using nullLOX barley minimises negative beer-staling components, provides stable, quality foam with no aged off-flavours, and keeps its fresh flavour for longer (http://www.null-lox. co.uk/).

Baxter [6] first suggested that barley LOX was a genotypic characteristic. Yang and Schwarz [7] suggested that kilning condition and genotypic variation may impact LOX isoenzyme survival in finished malt. Wu et al. [8] found significant genotypic variation in LOX-1 activity in several barley cultivars, suggesting that LOX-1 activity may be reduced through breeding.

To date, several null/low LOX-1 barley lines have been identified. Hirota et al. [9] discovered six LOX-1 null barley lines by surveying many landrace lines. These lines did not show any significant LOX-1 activity and lacked the authentic LOX-1 protein. Genetic analysis revealed that this null-LOX-1 trait was governed by a single recessive gene located at the LoxA locus on chromosome $4 \mathrm{H}$. The six LOX-1 null mutants shared similar features and the same unique polymorphism in a structural gene region, implying that these mutants might be derived from the same ancestral origin. Through mutation breeding, Oozeki et al. [10] obtained a LOX-1-deficient mutant line 'Daikei LM1' from sodium azide treated 'Karl' M2. DNA sequence analysis of the LOX-1 gene of 'DaikeiLM1' revealed that a single nucleotide substitution ( $\mathrm{C}$ to $\mathrm{T}$ ) resulted in a stop codon in the third exon of LOX-1. Using LOX-1 null barley in brewing can effectively improve flavour stability in beer without changing other important beer qualities [11]. A LOX-less commercial barley variety CDC PolarStar was successfully developed by successive backcross and molecular marker assisted selection of the mutant gene [12]. In addition, studies have shown that the Lox $15^{\prime}$-untranslated leader sequence was involved in embryo-specific expression; its leader sequence contains cis-elements regulating qualitative (tissue-specific) and quantitative gene expression and an enhancer element that increases activity of upstream promoter fragments in vivo [13]. These studies indicate that the structural gene of LOX-1 plays a key role in determining LOX content.

LOX content is also important in other crops. For example, LOX play a role in the development of unpleasant flavors in foods containing soybean by oxidation of polyunsaturated fatty acids. Null-LOX mutants have also been developed for soybean breeding [14].

In this study, we surveyed LOX activity among Australian barley varieties by sequencing the promoter and structural gene of Lox1 which represents different levels of LOX activity. We analysed the Lox1 gene nucleotide and deduced amino acid sequences, compared mutation sites among null-LOX-1 mutants, and determined its phylogenetic relationship among these varieties. Our investigation aimed to further understand genetic control of LOX activity, and provide a theoretical foundation for developing low-LOX malting barley cultivars, which may in turn improve the flavour stability of some beers.

\section{Methods \\ Materials}

The genetic material included 36 of the 65 barley varieties released in Australia since the 1950s and 5 advanced breeding lines (Additional file 1). All the materials are tworowed spring type. A sub-set of varieties-Hindmarsh, Gairdner, Skiff, Onslow, Clipper, Franklin, Moondyne and Chevalier-were selected to investigate the sequence variation of Lox1 gene based on their LOX activity (see Lipoxygenase Assay section below).

\section{Field trials}

The field plot was planted in a randomised complete block design in plots $1 \times 3 \mathrm{~m}^{2}$. Plants were grown at three sites in Western Australia with two replicates at each site. Harvested grains from each site were evaluated for their 
physical quality, and grains from the best site were used for micro-malting analysis.

\section{Micro-malting analysis}

Barley samples were cleaned and sieved over a $2.2 \mathrm{~mm}$ screen prior to micro-malting in a Joe White Systems micro-malting unit without additives. A standard malting schedule was used by steeping at $19^{\circ} \mathrm{C}$ for $7 \mathrm{~h}$ wet, $8 \mathrm{~h}$ air rest, $3 \mathrm{~h}$ wet, $4 \mathrm{~h}$ air rest, $1 \mathrm{~h}$ wet. Germination took $96 \mathrm{~h}$ $\left(48 \mathrm{~h}\right.$ at $18^{\circ} \mathrm{C}$ followed by $48 \mathrm{~h}$ at $16^{\circ} \mathrm{C}$ ), then moisture adjusted to $46 \%$ for $24 \mathrm{~h}$. Kilning was $2 \mathrm{~h}$ at $45^{\circ} \mathrm{C}, 3 \mathrm{~h}$ at $50^{\circ} \mathrm{C}, 4 \mathrm{~h}$ at $55^{\circ} \mathrm{C}, 3 \mathrm{~h}$ at $60^{\circ} \mathrm{C}, 3 \mathrm{~h}$ at $65^{\circ} \mathrm{C}, 3 \mathrm{~h}$ at $70^{\circ} \mathrm{C}$, $2 \mathrm{~h}$ at $75^{\circ} \mathrm{C}$, and $4 \mathrm{~h}$ at $80^{\circ} \mathrm{C}$. Malt rootlets were removed using a custom-made rootlet-removing machine (Fraser Fabrications P/L, Malaga, Western Australia).

\section{Lipoxygenase assay}

We used the Joe White Malting revised version of the Malt Lipoxygenase (LOX) (original assay from Baxter [6]). All processes were completed on ice unless otherwise indicated.

\section{Preparation of substrate solution ( 2.5 linoleic acid)}

Five milliliters of $0.05 \mathrm{M}$ borate buffer ( $\mathrm{pH} 9.0$ ) was added to a volumetric flask (10 mL) followed by $0.25 \mathrm{~mL}$ Tween20, $0.25 \mathrm{~mL}$ linoleic acid and $0.65 \mathrm{~mL} 1 \mathrm{M} \mathrm{NaOH}$. The contents were shaken gently in an ultrasonic bath with ice water until the solution became clear, then distilled water was added to $10 \mathrm{~mL}$.

\section{Enzyme extraction from finished malt}

Finished malts were milled in a Retsch ZM200 centrifugal mill (Retsch $\mathrm{GmBH}$, Germany) with a $1.0 \mathrm{~mm}$ screen; $5 \mathrm{~g}$ milled malt was transferred to $100 \mathrm{~mL}$ flask. $50 \mathrm{~mL}$ of acetate buffer ( $\mathrm{pH} 5.0$ ) containing $0.1 \mathrm{M} \mathrm{NaCl}$ was added and kept in ice water bath for 15 min with occasional shaking. The resulting solution was transferred to a $1.5 \mathrm{~mL}$ eppendorf tube and centrifuged for $5 \mathrm{~min}$ at $10000 \mathrm{rpm}$. The supernatant was subsequently transferred to a new eppendorf tube and stored on ice.

\section{Enzyme assay}

The temperature of the cell holder and phosphate buffer (0.1 M, pH 6.8) was equilibrated to $25^{\circ} \mathrm{C}$ by water circulation. $100 \mu \mathrm{L}$ enzyme extract and $2850 \mu \mathrm{L}$ phosphate buffer $(0.1 \mathrm{M}, \mathrm{pH} 6.8)$ was added to $50 \mu \mathrm{L}$ substrate solution, mixed, returned to the cell holder and absorbance recorded at $1 \mathrm{~min}$ and $4 \mathrm{~min}$ at $234 \mathrm{~nm}$. Blank absorbance was measured using $50 \mu \mathrm{L}$ substrate solution and $2950 \mu \mathrm{L}$ phosphate buffer at $1 \mathrm{~min}$.

\section{Calculation and expression of results}

One unit of LOX activity represents an increase in absorbance at $234 \mathrm{~nm}$ per minute, per gram malt on dry basis, as calculated using the following formula:

$$
\begin{aligned}
\text { LOX activity }= & \frac{\operatorname{Abs}(4 \mathrm{~min})-\operatorname{Abs}(1 \mathrm{~min})}{3} \\
& \times \frac{1}{5 \times(100-\mathrm{M} / 100)} \times \frac{50000}{\mathrm{~B}}
\end{aligned}
$$

where Abs (4 min) is absorbance at $234 \mathrm{~nm}$ at $4 \mathrm{~min}$ of reaction, $\mathrm{Abs}(1 \mathrm{~min})$ is absorbance at $234 \mathrm{~nm}$ at $1 \mathrm{~min}$ reaction, $M$ is moisture content of malt sample, and $B$ is volume $(\mu \mathrm{L})$ of enzyme extract of malt used.

\section{DNA extraction}

Genomic DNA was extracted from the leaves of twoweek-old seedlings for each variety following the phenol chloroform standard protocol. DNA samples were quantified using the Nanodrop and adjusted to a final concentration of about $25 \mathrm{ng} / \mu \mathrm{L}$ for PCR analysis.

\section{Primer design and PCR amplification for isolation of Lox1 promoter and gene}

The full-length Lox1 promoter sequence has been isolated from Himalaya [15] (NCBI database, U83904). Full-length cDNAs of the Lox1 gene have been isolated from barley varieties Triumph [3] (NCBI database, L35931) and Haruna Nijo (NCBI database, AK252639). Based on the sequences from the NCBI database (http://www.ncbi.nlm.nih.gov), PCR primers were designed for sequencing with 100200 bp overlaps between adjacent fragments (Additional file 2).

PCR reactions were carried out in a final volume of $50 \mu \mathrm{L}$ containing about $100 \mathrm{ng}$ of genomic DNA, 10× PCR buffer, $1.5 \mathrm{mM} \mathrm{MgCl}_{2}, 200 \mu \mathrm{M}$ of each dNTP, $400 \mathrm{nmol}$ of each primer, and one unit of Taq DNA polymerase. The reaction was initially denatured at $95^{\circ} \mathrm{C}$ for $5 \mathrm{~min}$, followed by 35 cycles of $95^{\circ} \mathrm{C}$ for $30 \mathrm{~s}$, annealing for $45 \mathrm{~s}$ and $72^{\circ} \mathrm{C}$ for $1 \mathrm{~min}$. The PCR was terminated at $72^{\circ} \mathrm{C}$ for $7 \mathrm{~min}$.

\section{Transformation, cloning and sequencing}

The PCR-amplified DNA was excised separately from agarose gels and extracted using QIAEX II Gel Extraction (QIAGEN). The DNA sequence was ligated into $\mathrm{pGEM}^{\ominus}-\mathrm{T}$ Easy Vectors (Promega) according to manufacturer recommendations. Competent E. coli cells, strain JM109, were transformed and the clones screened by blue/white colony selection. Plasmid DNA from the colony was isolated by the alkali lysis method [16]. Recombinant DNA was screened for appropriate insert size by digestion with EcoRI restriction enzyme. The pGEM-T Easy cloned products were sequenced with primers M13F and M13R. Sequencing reactions were performed on PCR products 
according to manufacturer recommendations, using BigDye labeling sequencing reaction mixture. Sequences were read on an Applied Biosystems 3730 DNA sequencer (SABC, Murdoch University, Western Australia).

\section{Data analysis}

Sequences were edited to remove the vector sequence and extra restriction sites. The promoter region and intron-exon structure of the barley LOX-1 coding region were deduced by comparing the nucleotide sequence of the barley published Lox1 cDNA sequence (NCBI database L35931 and AK252639). The amino acid sequence of Lox 1 was deduced using Translate Tools in the ExPaSy web server (http://au.expasy.org/tools/dna.html). Multiple alignments of sequences were used with Clustal X (v 1.82) and performed using GeneDoc (v2.5). Phylogenetic reconstructions were done using the MEGA4.0 package. Distance matrices were constructed using the Kimura two-parameter model and trees constructed using the neighbour-joining algorithm. The dataset was re-sampled 1000 times using the bootstrap method. Phylogenetic analyses are presented for the Lox1 DNA sequences.

\section{Results}

Phenotypic variation of LOX in australian barley varieties Forty-one barley cultivars and advanced breeding lines were surveyed for LOX activity, which included major barley varieties grown in Australia since 1950s (Additional file 1). LOX content varied markedly among the 41 Australian barley cultivars and advanced breeding lines, ranging from 22.3 to $46.5 \mathrm{U} / \mathrm{g}$. LOX content has gradually decreased in Australian barley cultivars over the last 60 years (Figure 1; $\left.R=-0.46^{* *}, P<0.01\right)$, although there is markedly variation. On average, malting cultivars had about 17 less LOX compared with feed varieties $(P<0.01)$. Hindmarsh, Gairdner,

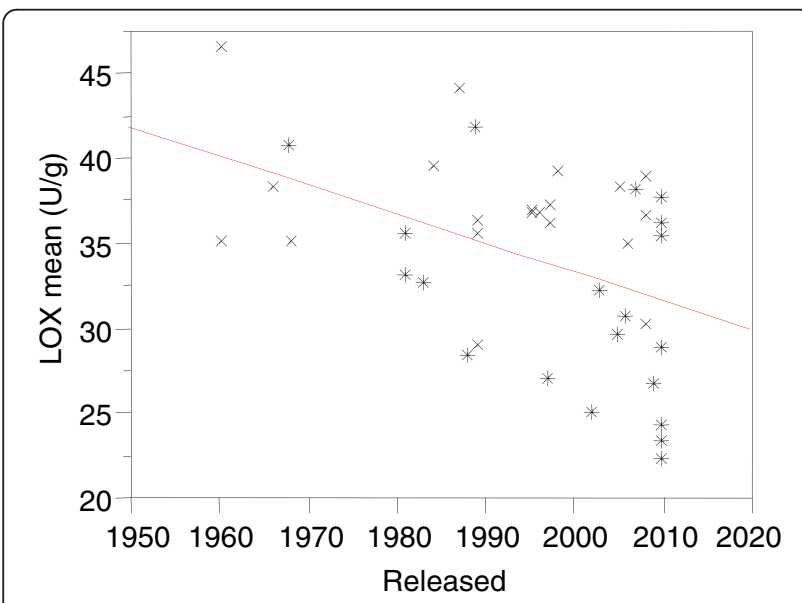

Figure 1 Variation trends of LOX content in 41 Australian barley cultivars over the last 60 years $\left(R=-0.46^{* *}, P<0.01\right)$. The ' $x$ ' indicated feed cultivars and the ${ }^{\prime * \prime}$ indicated malting cultivars.
Onslow, Skiff, Hamelin, Flagship, WABAR2480, WABAR 2481 and WABAR2482 had the lowest LOX and could be used to develop barley varieties with lower levels of LOX.

\section{Nucleotide sequence of Lox1 promoter}

The previous study demonstrated that cis-acting elements within the untranslated leader sequence of the Lox1 gene are essential for embryo-specific expression, and that it is possible to modify tissue-specificity of other genes by inserting this leader sequence. Deletion/ replacement analysis of the Lox1 leader sequence, combined with transient expression in germinating embryos and in vitro transcription/translation assays, suggests that essential promoter or enhancer element(s) involved in Lox1 expression in embryos are located between -129 and $-75 \mathrm{bp}$ [13]. In this study, $1101 \mathrm{bp}$ (from -1076 to +12 ) Lox1 promoter fragment sequences were obtained from eight different barley varieties with different LOX contents. The sequences of these eight varieties were compared with the Himalaya promoter sequence (NCBI database, U83904) [15]. Alignment showed that the Australian varieties differ from the Himalaya variety. The eight sequenced varieties shared high degrees of identity. Franklin had one base pair difference at position -807 (Himalaya -795) $(\mathrm{C} \rightarrow \mathrm{T})$ and Skiff had one variation at position -702 (Himalaya -690$)(A \rightarrow G)$. These variations are located outside the known functional domain (data not shown) [13].

\section{Analysis of Lox 1 structural gene}

Lox1 sequence contains 7 exons and 6 introns, and the length of the complete Lox 1 sequence is $4165 \mathrm{bp}$ (Moondyne, Vintage Onslow, Gairdner, Franklin, Chevalier, Barke, Neruda) (Figure 2) or 4188 bp (Clipper, Hindmarsh, Skiff. The 4188 bp variant, not shown in Figure 2, has 9 bp and $16 \mathrm{bp}$ insertion in intron 1 and intron 2, respectively, and 2 bp deletion in intron 3 compared with the 4165 bp variant.

Lox1 gene sequences of 11 varieties were used for alignment in this study, including eight varieties representing different LOX levels (high/low). The others were the wild types (Vintage (AX469865), Neruda (CS172656), Barke (CS 172652)) of the low/null LOX-1 mutants (Line G (AX469 868), A168 (CS172657), D112 (CS172653)), (http://wheat. pw.usda.gov/GG2/index.shtml). Forty-three variant positions were identified among these 11 sequences (Additional file 3). Alignment results identified two types of sequences: (1) those with the same sequence, which included Skiff, Clipper and Hindmarsh, and (2) those which shared a similar sequence, except Vintage and Moondyne with a few variations. A phylogenetic analysis of the 11 varieties is presented in Figure 3. The phylogenetic tree indicates that the Lox1 gene sequence of Skiff, Clipper and Hindmarsh had the same origin; Lox1 gene of Chevalier, Franklin, 


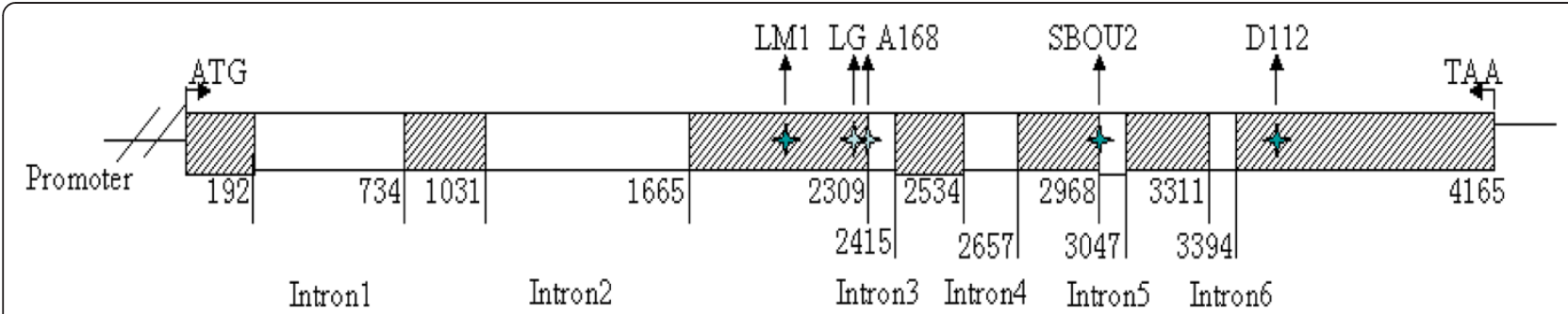

Figure 2 Gene structure of Lox 1 gene-composed of 7 exons (stippled boxes) and 6 introns (white boxes)—and the mutation positions in five null/low LOX-1 mutant lines. Stars indicate mutation positions.

Onslow, Barker, Gairdner, Neruda, Vintage and Moondyne may belong to a different origin.

\section{Analysis of coding regions}

The cDNA sequences of Triumph (L35931), Haruna Nijo (AK252639) and Vintage (AX469847) were retrieved from the NCBI database (http://www.ncbi.nlm.nih.gov). cDNA sequences of the eight barley varieties were deduced from the sequenced genomic DNA. Alignment of the cDNA sequences among these varieties identified 19 single nucleotide substitutions (Additional file 3). Three single nucleotide replacements resulted in amino acid substitutions His/Gln-64, Gly/Glu-231, Pro/Ala-830 in the Lox1 gene coding region (Figure 4). The alignment of the deduced amino acid sequences further supports the two distinguished haplotypes of Lox1 gene in the current barley varieties. Further study is required to understand relationship of the amino acid substitutions and LOX activity. Comparing nucleotide sequences with the wild type LOX-1 gene, all null-LOX-1 lines-Daikei LM1, A168, D112 and SBOU2-shared a single nucleotide substitution $[9,10]$, which introduced an internal stop codon (Figure 2, Additional file 4) (Patent WO02053721). The low LOX-1 barley, Line $\mathrm{G}$, had two nucleotide substitutions in 2 exons, one of which (at position +2279) led to a nonconservative 368 amino acid substitution (Glycine $\rightarrow$ Aspartate) in the expressed protein (Patent WO02053721). The insertion of a charged amino acid residue at this

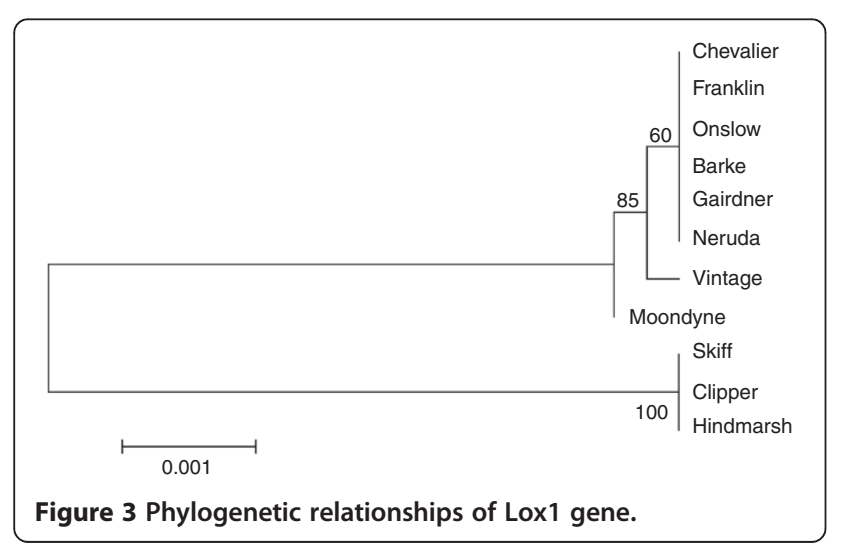

position is thus likely to disturb the structural and functional properties of the enzyme.

\section{Discussion}

In the brewing industry, LOX-1 is regarded as a negative enzyme that worsens the flavour and foam stabilities of beer. Therefore, a barley cultivar with lower LOX-1 content or heat-labile LOX-1 is preferable for brewing. A previous study suggested that LOX activity is significantly $(P>0.05)$ affected by cultivar, while interactions of environment $\times$ cultivar are not significant [8]. Both the level of gene expression and the stability and specific activity determine the level of enzyme activity in the tissue.

Hirota et al. [17] identified a major quantitative trait locus (QTL) for LOX activity on chromosome $4 \mathrm{H}$, which was located at the same locus as the structural gene (Lox1), explaining 82 of phenotypic variance. A minor QTL was detected on chromosome 7H. More recently, Jin et al. [18] found another 3 QTLs controlling LOX content in the Stirling/Harrington DH population. One QTL at chromosome $5 \mathrm{HL}$ contributed to 39 of genetic variation in LOX content. The second QTL, close to the centromere region of chromosome $5 \mathrm{H}$, accounted for 17 of genetic variation. A minor QTL on chromosome $2 \mathrm{H}$ explained 6 of genetic variation but was significant in both years. These studies indicate that the structural gene of LOX-1 plays a key role in determining LOX content. However, LOX content can also be controlled by other genes or trans-regulation.

In the present study, we surveyed LOX content in Australian commercial barley varieties from the 1950s. In general, malting barley varieties have less LOX than feed varieties, and modern varieties had less LOX than older varieties (Figure 1; Additional file 1). As LOX content has not been a selection criterion in breeding programs to date, we speculate that low LOX is associated with other preferred malting quality traits. This phenomenon has also been observed in QTL mapping for many traits including enzyme activity for alpha-amylase and beta-glucanase [18]. A recently study demonstrated 9-lipoxygenase as modulator of local and systemic defense in Arabidopsis. The lox1 mutant enhanced susceptibility and partially impaired activation of systemic acquired resistance [19]. Further study is 


\begin{tabular}{|c|c|c|c|c|c|c|}
\hline a & $|\ldots|$. & $b$ & $\ldots|\ldots, \ldots| \ldots|\ldots|$ & c & $\ldots|\ldots|$ & $\ldots .|\ldots|$ \\
\hline & 75 & & 225 & & 825 & 835 \\
\hline Hindmarsh & AVDHDNGGRG KVGAEAELEQ & Hindmarsh & DHPYPRRGRT GRKPNASDPS & Hindmarsh & PELKNRNGPP & KFPYMLLYPN \\
\hline Clipper & AVDHDNGGRG KVGAEAELEQ & Clipper & DHPYPRRGRT GRKPNASDPS & Clipper & PELKNRNGPP & KFPYMLLYPN \\
\hline Skiff & AVDHDNGGRG KVGAEAELEQ & Skiff & DHPYPRRGRT GRKPNASDPS & Skiff & PELKNRNGPE & KFPYMLLYPN \\
\hline Moondyne & AVDGDNGGRG KVGAEAELEQ & Moondyne & DHPYPRRGRT FRKPNASDPS & Moondyne & PELKNRNGP & KFPYMLLYPN \\
\hline Vintage & AVDGDNGGRG KVGAEAELEQ & Vintage & DHPYPRRGRT RRKPNASDPS & Vintage & PELKNRNGPA & KFPYMLLYPN \\
\hline Chevalier & AVDGDNGGRG KVGAEAELEQ & Chevalier & DHPYPRRGRT RRKPNASDPS & Chevalier & PELKNRNGPA & KFPYMLLYPN \\
\hline Triumph & AVDGDNGGRG KVGAEAELEQ & Triumph & DHPYPRRGRT ARKPNASDPS & Triumph & PELKNRNGPA & KFPYMLLYPN \\
\hline Onslow & AVIGDNGGRG KVGAEAELEQ & Onslow & DHPYPRRGRT $A R K$ KNASDPS & Onslow & PELKNRNGPA & KFPYMLLYPN \\
\hline Franklin & AVDGDNGGRG KVGAEAELEQ & Franklin & DHPYPRRGRT RRKPNASDPS & Franklin & PELKNRNGPA & KFPYMLLYPN \\
\hline Gairdner & AVDGDNGGRG KVGAEAELEQ & Gairdner & DHPYPRRGRT ERKPNASDPS & Gairdner & PELKNRNGPA & KFPYMLLYPN \\
\hline Haruna Nijo & AVDGDNGGRG KVGAEAELEQ & Haruna Nijo & DHPYPRRGRT ARKPNASDPS & Haruna Nijo & PELKNRNGPA & KFPYMLLYPN \\
\hline
\end{tabular}

Figure 4 Alignment results among amino acid sequences deduced from different plasmid sequencing in this paper and others published in Graingene2.

required to understand if the selection of low LOX enhanced disease susceptibility in the good malting quality barley variety, e.g. Baudin.

Nine barley cultivars and breeding lines-Hindmarsh, Skiff, Gairdner, Onslow, Hamelin, Flagship, WABAR2 480, WABAR2481 and WABAR2482-were identified with lower LOX contents. Hamelin, Flagship, WABAR 2480, WABAR2481 and WABAR2482 shared common ancestry with variety Harrington. It is likely that these varieties and breeding lines have common genes for controlling low LOX. In a previous study, two QTLs were identified from Harrington controlling low LOX content on chromosome 5HC and 5HL [18]. As there is no LOX structural genes in the chromosomal regions, the low LOX content from Harrington and its derived varieties should be due to trans-regulation. The same regions were also reported to regulate the activity of alpha-amylase and beta-glucanase [20]. Furthermore, the two QTL coincided with the QTLs for seed dormancy/pre-harvest sprouting. As the pre-harvest sprouting susceptible alleles were associated with low LOX content, these varieties may only be used for breeding low-LOX varieties in areas with low risk of pre-harvest sprouting [18].

Onslow is one of the parents of Gairdner; we speculate that low LOX in these two varieties share a common mechanism. These two varieties are reasonably tolerant to pre-harvest sprouting, so may have a different mechanism for low LOX than the other varieties. Sequence analysis showed high identity of the LOX-1 gene in these two varieties as well as the normal-LOX varieties (Figure 4; Additional file 3). Further research is needed to understand the low-LOX mechanism in Gairdner and Onslow.

Hindmarsh and Skiff have a unique LOX-1 gene sequence compared with other varieties. These included one
10 bp insertion, one 17 bp insertion, one 2 bp deletion and 39 single nucleotide substitutions (Additional file 3) which resulted in three amino acid changes (Figure 4). It is not clear if these variations are associated with LOX content, as the third variety Clipper had the same sequence, but different LOX content. Other mechanisms may be involved in controlling LOX content in Clipper.

Thermostability is another key factor to determine final LOX content in malt. Segregation analysis revealed that LOX thermostability types in the Steptoe/Morex DHLs were governed by a single locus, located at the same locus as the LOX-1 structural gene of chromosome $4 \mathrm{H}$. It is clear that the factor controlling LOX thermostability types was located at the LoxA locus which corresponds with the LOX-1 structural gene [4]. To understand the diversity in the thermostability of seed lipoxygenase-1 (LOX-1), Hirota et al. [21] investigated 1040 cultivars of barley (Hordeum vulgare ssp. vulgare): the relative thermostability of LOX-1 (LOX-RTS) in these lines had a bimodal frequency distribution and were categorised into high and low thermostability types (H-type and L-type, respectively). Thus, it is likely that thermostability is controlled by the structural variation of LOX-1 as demonstrated in beta-amylase [22] Testing is underway to see if the three amino acid substitutions in Hindmarsh, Skiff and Clipper result in changes in thermostability (Figure 4).

\section{Conclusion}

Lipoxygenase activity has been reduced in the malting barley varieties in the last 60 years although it is only recognized as a malting quality trait recently. In general, malting barley varieties have less LOX than feed varieties, and modern varieties had less LOX than older varieties. There are clear haplotypes of the lipoxygenase structual 
gene, which is an important factor for controlling lipoxygenase activity. The polymorphisms detected in the structural gene can be used to design molecular markers for selection of low LOX haplotype. Further study is required to understand the relationship between the haplotypes and LOX activity or thermostability. But other mechanisms also existed for controlling lipoxygenase activity. The results suggest that it is possible to develop barley varieties with lower LOX by combining different mechanisms.

\section{Additional files}

Additional file 1: List of barley cultivars used in this study including their origins and type.

Additional file 2: PCR primers for amplification of DNA fragments.

Additional file 3: List of variable positions in the Lox 1 sequence of different barley varieties.

Additional file 4: Development of low/null-LOX malting barley cultivars.

\section{Abbreviations}

Aa: Amino acid; HPOD: Hydroperoxide; LOX: Lipoxygenase; NJ: Neighbor-joining algorithm; Nt: Nucleotide; THOD: Trihydroxyoctadecenoic acid.

\section{Competing interests}

The author's declare that they have no competing interests.

\section{Authors' contributions}

HY: data analysis and draft the paper; SH: micromalting and enzyme assays; XZ: DNA sequencing; BP: conducted field trial; DW: experimental design; MJ: supervised experiment and draft paper; XS: data analysis; $\mathrm{CL}$ : data analysis and finalized the paper.

\section{Acknowledgements}

This study was partially supported by the Australian Grain Research and Development Corporation and Research Projects 2013CBA01403 and 2012C12902-2

\section{Author details}

${ }^{1}$ State Key Lab of Rice Biology and Key Lab of the Ministry of Agriculture for Nuclear-Agricultural Sciences, Zhejiang University, Hangzhou 310029, P.R. China. ${ }^{2}$ Department of Agriculture and Food, Government of Western Australia, 3 Baron-Hay Court, South Perth, WA 6151, Australia. ${ }^{3}$ The State Agricultural Biotechnology Centre, Murdoch University, Murdoch, WA 6150, Australia.

Received: 10 December 2013 Accepted: 10 March 2014 Published: 19 March 2014

\section{References}

1. Fischer AM, Dubbs WE, Baker RA, Fuller MA, Stephenson LC, Grimes HD: Protein dynamics, activity and cellular localization of soybean lipoxygenases indicate distinct functional roles for individual isoforms. Plant J 1999, 19(5):543-554

2. Schmitt NF, VanMechelen JR: Expression of lipoxygenase isoenzymes in developing barley grains. Plant Sci 1997, 128(2):141-150.

3. Vanmechelen JR, Smits M, Douma AC, Rouster J, Cameronmills V, Heidekamp F, Valk BE: Primary Structure of a Lipoxygenase from Barley-Grain as Deduced from Its Cdna Sequence. Biochim Biophys Acta, Lipids Lipid Metab 1995, 1254(2):221-225

4. van Mechelen JR, Schuurink RC, Smits M, Graner A, Douma AC, Sedee NJA, Schmitt NF, Valk BE: Molecular characterization of two lipoxygenases from barley. Plant Mol Biol 1999, 39(6):1283-1298.

5. Shimase M, Saito T, Takaoka T, Kihara M, Yamada S: Breeding of Lipoxygenase-1-less Malting Barley Variety CDC PolarStar and Effect of Lipoxygenase-1-less Trait on Beer Quality at Pilot and Commercial Scale Brewing. BrewingSci-Monatsschrift für Brauwissenschaft 2013, 66:37-45.
6. Baxter ED: Lipoxidases in Malting and Mashing. J Inst Brew 1982, 88(6):390-396.

7. Yang GS, Schwarz PB: Activity of Lipoxygenase Isoenzymes during Malting and Mashing. J Am Soc Brew Chem 1995, 53(2):45-49.

8. Wu Y, Schwarz PB, Doehlert DC, Dahleen LS, Horsley RD: Rapid separation and genotypic variability of barley (Hordeum vulgare L) lipoxygenase isoenzymes. J Cereal Sci 1997, 25(1):49-56.

9. Hirota N, Kaneko T, Kuroda H, Kaneda H, Takashio M, Ito K, Takeda K: Characterization of lipoxygenase-1 null mutants in barley. Theor Appl Genet 2005, 111(8):1580-1584.

10. Oozeki M, Nagamine T, Ikeda TM, Suzuki Y, Sekiwa T, Yamaguchi E, Kato T: Genetic variation in lipoxygenase activity among Japanese malting barley cultivars and identification of a new lipoxygenase-1 deficient mutant. Breed Res 2007, 9:55-61.

11. Hirota N, Kuroda H, Takoi K, Kaneko T, Kaneda H, Yoshida I, Takashio M, Ito K, Takeda K: Brewing performance of malted lipoxygenase-1 null barley and effect on the flavor stability of beer. Cereal Chem 2006, 83(3):250-254.

12. Hoki T, Saito W, Hirota N, Shirai M, Takoi K, Yoshida S, Shimase M, Saito T, Takaoka T, Kihara M, Yamada S: Breeding of lipoxygenase-1-less malting barley variety CDC PolarStar and effect of lipoxygenase-1-less trait on beer quality at pilot and commercial scale brewing. Brewing Science 2013, 66:37-45.

13. Rouster J, van Mechelen J, Cameron-Mills V: The untranslated leader sequence of the barley lipoxygenase 1 (Lox 1) gene confers embryospecific expression. Plant J 1998, 15(3):435-440.

14. Lenis J, Gillman J, Lee J, Shannon J, Bilyeu K: Soybean seed lipoxygenase genes: molecular characterization and development of molecular marker assays. Theor App/ Genet 2010, 120(6):1139-1149.

15. Rouster J, Leah R, Mundy J, CameronMills V: Identification of a methyl jasmonate-responsive region in the promoter of a lipoxygenase 1 gene expressed in barley grain. Plant J 1997, 11(3):513-523.

16. Sambrook J, Russel DW: Plasmids and their usefulness in molecular cloning. Molecular Cloning 2001, 1.1(1):31-35.

17. Hirota N, Kaneko T, Ito K, Takeda K: Mapping a factor controlling the thermostability of seed lipoxygenase-1 in barley. Plant Breed 2006, 125(3):231-235.

18. Jin $X$, Harasymow S, Bonnardeaux $Y$, Tarr A, Appels R, Lance $R$, Zhang G, Li C: QTLs for malting flavour component associated with pre-harvest sprouting susceptibility in barley (Hordeum vulgare L.). J Cereal Sci 2011, 53(2):149-153.

19. Vicente J, Cascon T, Vicedo B, Garcia-Agustin P, Hamberg M, Castresana C: Role of 9-Lipoxygenase and alpha-Dioxygenase Oxylipin Pathways as Modulators of Local and Systemic Defense. Mol Plant 2012, 5(4):914-928.

20. Li C, Ni P, Francki M, Hunter A, Zhang Y, Schibeci D, Li H, Tarr A, Wang J, Cakir M, Yu J, Bellgard M, Lance R, Appels R: Genes controlling seed dormancy and pre-harvest sprouting in a rice-wheat-barley comparison. Funct Integr Genomics 2004, 4(2):84-93.

21. Hirota N, Kaneko T, Ito K, Takeda K: Diversity and geographical distribution of seed lipoxygenase-1 thermostability types in barley. Plant Breed 2008, 127(5):465-469.

22. Evans D, Li C, Eglinton JK: The Properties and Genetics of Barley Malt Starch Degrading Enzymes. In Genetics and Improvement of Barley Malt Quality. Edited by Zhang GP, Li CD. Spinger; 2010:143-189.

doi:10.1186/1471-2156-15-36

Cite this article as: Ye et al:: Sequence variation and haplotypes of lipoxygenase gene LOX-1 in the Australian barley varieties. BMC Genetics 2014 15:36. 